\title{
Angst, depresjon og psykiatrisk epidemiologisk forskning i Nord-Trøndelag
}

\author{
Alv A. Dahl ${ }^{1}$, Marit Bjartveit Krüger ${ }^{2}$, Nils Håvard Dahl ${ }^{2}$, Eystein Stordal ${ }^{3}$ \\ og Arnstein Mykletun ${ }^{4}$ \\ ${ }^{1}$ Klinikk for psykiatri, Aker universitetssykehus HF, Oslo \\ ${ }^{2}$ Psykiatrisk klinikk, Helse Nord-Trøndelag HF, Sykehuset Levanger \\ ${ }^{3}$ Psykiatrisk klinikk, Helse Nord-Trøndelag HF, Sykehuset Namsos \\ ${ }^{4}$ HEMIL-senteret, Det psykologiske fakultet, Universitetet $i$ Bergen
}

Korresponderende forfatter: Professor dr. med. Alv A. Dahl, Klinikk for psykiatri, Aker universitetssykehus HF, Sognsvannsveien 21 , 0320 Oslo Telefon: 22923820 Telefax: $22923971 \quad$ E-post: a.a.dahl@psykiatri.uio.no

\begin{abstract}
SAMMENDRAG
Hospital angst og depresjonsskala (HADS) ble valgt som selvutfyllingsinstrument for angst og depresjon i Helseundersøkelsen i Nord-Trøndelag 1995-97 (HUNT-II). Anledning til analyser av disse dataene, og kravet om en intervensjon rettet mot individene med høyest HADS-skår, var grunnlaget for IDANT-gruppen. Gruppen har etablert epidemiologisk forskning ved de psykiatriske klinikkene i Namsos og Levanger med sikte på doktorgrader begge steder slik at det skapes et varig grunnlag for psykiatrisk forskning i Nord-Trøndelag. Resultatene av intervensjonsstudien og en rekke studier med angst/depresjon som utfallsvariabler med en rekke prediktorvariabler presenteres. Målsetningen om analyse og publikasjon av psykiatridata fra HUNT-II i Nord-Trøndelag er i ferd med å oppfylles, forhåpentlig med et bærekraftig forskningsmiljø som følge.
\end{abstract}

Dahl AA, Krüger MB, Dahl NH, Stordal E, Mykletun A. Anxiety, depression and psychiatric epidemiologic research in Nord-Trøndelag County. Nor J Epidemiol 2002; 12 (3): 347-353.

\section{ENGLISH SUMMARY}

The Hospital Anxiety and Depression Rating Scale (HADS) was chosen as the self-rating instrument for anxiety and depression in the Health Study of Nord-Trøndelag 1995-97 (HUNT-II). The IDANTgroup was established in order to take care of the intervention study and the analysis and publication of the anxiety and depression data. The group has established research in psychiatric epidemiology at the departments of psychiatry in Levanger and Namsos. The results so far from the intervension and the projects with anxiety and depression as criterion variables are presented. The aim of analysis and publication of the data from the psychiatric milieu in Nord-Trøndelag County has been fulfilled, and hopefully with a permanent research milieu for psychiatric epidemiology as a result.

\section{BAKGRUNN}

Psykiske lidelser er et sentralt folkehelseproblem, og epidemiologiske undersøkelser fra utlandet har vist at nesten halvparten av befolkningen får en definert psykisk lidelse i løpet av livet $(1,2)$. Nylig er slik livstidsprevalens også bekreftet $i$ en norsk undersøkelse (3). Helsepolitisk ble det i økende grad satt fokus på psykisk helse og det psykiatriske behandlingstilbudet $i$ Norge utover i 1990-årene. TV-aksjonen 1992 samlet inn penger til psykiatrisk forskning, og en rekke kjente mennesker stod fram med sine psykiske lidelser. Dette kulminerte i Stortingsmeldingen om psykiatri (4) og Opptrapningsplan for psykisk helse 1999-2006 (5).

Denne utviklingen gjorde det naturlig å vurdere om psykiske problemer skulle komme tyngre inn i de nasjonale og regionale helseundersøkelsene av befolkningen gjennomført av Statens helseundersøkelser med ulike samarbeidspartnere. Den første helseundersøkelsen i Nord-Trøndelag fylke 1984-86 (HUNT-I) omfattet hypertoni, diabetes, lungesykdommer og livskvalitet (6). $\AA$ ta med mer spesifikke spørsmål om psykiske problemer, var dermed en ny problemstilling for de som hadde gjennomført HUNT-I, og som i hovedsak hadde erfaring med å kartlegge somatiske forhold i befolkningen. Å kartlegge psykiske plager syntes å ligge i tiden både holdningsmessig og helsepolitisk, og det ble spørsmål om å ta med dette da Helseundersøkelsen i Nord-Trøndelag 1995-97 (HUNT-II) ble planlagt. Samtidig var man i tvil om dette av frykt for at slike spørsmål kunne virke provoserende, og dermed kunne skremme folk bort fra undersøkelsen. Det var også 
spørsmål om hvilke psykiske plager som kunne kartlegges meningsfylt med noen få spørsmål på den begrensede plassen i de aktuelle spørreskjema. Etter grundig vurdering valgte man å kartlegge nivået av angst og depresjon, som er de mest utbredte psykiske problemene i befolkningen ved siden av somatisering og skadelig alkoholkonsum. Etter å ha sett på dokumentasjonen for aktuelle kartleggingsinstrumenter, valgte man å bruke Hospital angst- og depresjonsskala (HADS) (7) i HUNT-II.

HUNT-II var et samarbeidsprosjekt mellom Statens helseundersøkelser (SHUS), Folkehelsa med sin avdeling i Verdal og Nord-Trøndelag fylke. Da HUNT-I ble gjennomført, var det begrenset epidemiologisk forskningskompetanse i Nord-Trøndelag, og undersøkelsen ble blant annet brukt til å styrke denne kompetansen innen somatiske lidelser. For øvrig ble mye av forskningen i HUNT-I gjennomført utenfor NordTrøndelag. I forbindelse med HUNT-II var det naturlig å tenke seg at kompetansen innen psykiatrisk epidemiologisk forskning burde styrkes i fylket.

\section{PsYkiatri I NORD-TrøNdElaG}

Den voksenpsykiatriske spesialisthelsetjenesten i Nord-Trøndelag er lokalisert til Psykiatrisk klinikk, Sykehuset Namsos og Psykiatrisk klinikk, Sykehuset Levanger. Disse klinikkene omfatter både sengeavdelinger og poliklinikker, og fra disse basene drives det omfattende konsulentbistand til kommunehelsetjenesten. Ved Sykehuset Namsos ble det i 1968 etablert en "nerveklinikk" som var første del av det som ble en sykehusavdeling med full behandlingskjede fra 1979. Forskningen ved avdelingen har vesentlig dreidd seg om multisenter medikamentutprøvning og testpsykologi (8). I 1993 skjedde en flyulykke ved Namsos, og i den forbindelse ble det satt i gang et prosjekt med studier av overlevende ledet av psykolog Erling Johansen med veiledning fra NTNU. Det har vært publisert flere rapporter fra denne ulykken $(9,10)$.

Psykiatrisk avdeling, Sykehuset Levanger ble åpnet i november 1980 og utbygd over de neste årene til klinisk og poliklinisk seksjon med full behandlingskjede, også for psykiatriske pasienter med problematikk relatert til rus og til psykisk utviklingshemming. To av overlegene ved avdelingen hadde tidligere disputert innenfor andre fagområder (Reidun Olstad: immunologi og Jan Egil Wold: histologi). Sammen med overlege Hal Sexton startet de forskning ved avdelingen, og Sexton disputerte i 1992 ved NTNU på et arbeid fra avdelingen (11).

Ved planleggingen av HUNT-II fra 1992 ble avdelingsoverlegene ved de psykiatriske klinikkene i Namsos og Levanger invitert til å komme med innspill til kartleggingen av psykiske problemer, og både Eystein Stordal i Namsos og Marit Bjartveit Krüger og Nils Håvard Dahl i Levanger var aktive i dette arbeidet. Marit Bjartveit Krüger var i 1993-95 klinisk stipendiat ved Instituttgruppe for psykiatri ved Universitetet $\mathrm{i}$ Oslo, der hun hadde professor Alv A. Dahl som veileder. I 1995 ble Dahl trukket inn i arbeidet med kartlegging av psykiatri i HUNT-II, og sammen gikk Stordal, Dahl, Bjartveit Krüger og Dahl inn for at HADS skulle være måleinstrumentet for psykiske problemer $i$ HUNT-II. Dette fikk tilslutning i styringsgruppen for HUNT-II, men gruppen krevde også at høy skår for angst og/eller depresjon måtte meldes tilbake til pasienten og hans lege på samme måte som høyt blodtrykk eller høy kolesterol utløste tilbakemelding. Styringsgruppen sa altså ja til HADS, men krevde samtidig at forslagsstillerne umiddelbart utformet en intervensjonsstudie mot depresjon og angst i HUNT-II.

Opplegget for denne intervensjonen var klart da HUNT-II startet i august 1995, og de fire som hadde arbeidet for HADS og laget intervensjonsopplegget etablerte seg som IDANT-gruppen (Intervensjon mot Depresjon og Angst i Nord-Trøndelag). Gruppens formål var å sørge for gjennomføringen av Intervensjonen mot depresjon og angst hos legene i kommunene, og å analysere og publisere data om angst og depresjon fra HUNT-II lokalt i Nord-Trøndelag. Til intervensjonsdelen hørte systematisk opplæring i utredning og behandling av angst og depresjon for alle ansatte ved de psykiatriske poliklinikkene i fylket, samt tilbud om tilsvarende opplæring av alle allmennpraktiserende leger i fylket.

\section{MAteriale OG METOder}

\section{HUNT-II - deltakelse og opplegg}

Ut fra oppdaterte lister fra Statistisk sentralbyrå var det 92.936 personer i alder 20 år og eldre i Nord-Trøndelag som kunne delta i HUNT-II, og 66.140 (71,2\%) deltok i undersøkelsen (www.hunt.folkehelsa.no). De aktuelle personene mottok en personlig invitasjon om å delta med tid og sted for lokalt fremmøte til fysiske undersøkelser samt et formular (skjema 1) som de skulle medbringe til undersøkelsen. 65.220 individer fylte ut skjema 1 . Ved fremmøte ble det tatt blod- og urinprøve, og høyde, vekt og blodtrykk ble målt. I tillegg fikk deltakerne med seg et skjema 2 som de skulle fylle ut hjemme og returnere $\mathrm{i}$ posten innen to uker. 57.316 individer fylte ut skjema 2 og 57.211 fylte ut både skjema 1 og 2. Deltakerne skrev under på et samtykkeskjema om hvordan deres svar og prøver kunne brukes. Dette skjemaet og helseundersøkelsen for øvrig var godkjent av Regional komitè for medisinsk forskningsetikk i helseregion IV.

Fra august 1995 til juni 1997 dekket undersøkelsen systematisk alle de 24 kommunene i Nord-Trøndelag, og undersøkelsen ble godt annonsert lokalt. Individer som var på institusjoner som aldershjem, ble undersøkt der de oppholdt seg. De innsamlete opplysningene ble lagt inn i datafiler ved Statens helseundersøkelser, og anonymiserte filer ble senere rettet og kvalitetssikret 
ved Folkehelsa Verdal. Datafiler klare for analyser ble utlevert våren 1998.

Skjema 1 og 2 omfattet spørsmål om sosiodemografi, somatisk og psykisk helse og sykdom, levekår, boligforhold, mosjon, bruk av medikamenter og rusmidler, matvaner, bruk av helse- og kommunale tjenester, forhold til naboer og lokalmiljø samt syn på seg selv. Mange av disse spørsmålene hadde også vært brukt i den første helseundersøkelsen i Nord-Trøndelag (HUNT-I) 1984-86. HUNT-II ble organisert på tilsvarende måte som HUNT-I, og til den første helseundersøkelsen ble 87.285 personer i alderen 20 år og eldre invitert, 85.100 var aktuelle for deltakelse, og 74.977 deltok $(88,1 \%)(5)$.

Fremmøtet i HUNT-II var altså klart lavere enn i HUNT-I, og fremmøte var lavest i de yngre aldersklassene. På grunn av begrensede opplysninger var det vanskelig å gjøre en mer omfattende frafallsanalyse for å karakterisere de som ikke møtte til HUNT-II sammenlignet med de som deltok i undersøkelsen. Med en vektingsprosedyre var det mulig å korrigere for kjønn og 10-års aldersgrupper i forhold til manglende frammøte og i forhold til sammensetningen av hele den norske befolkning slik den var i 1996.

\section{Måling av angst og depresjon}

I HUNT-II ble angst og depresjon kartlagt med selvutfyllingsinstrumentet HADS. HADS ble utviklet i 1983 (7) som en test for måling av angst- og depresjonsnivået hos pasienter innlagt $i$ somatiske sykehusavdelinger. HADS var dermed i utgangspunktet renset for angst- og depresjonssymptomer som kunne skyldes somatisk sykdom, slik som for eksempel lite energi eller konsentrasjonsproblemer. Instrumentet var siktet inn på mildere patologi, fordi skjema fokusert på tyngre patologi gjerne ga små utslag hos somatiske pasienter ('floor effect'). HADS hadde vist seg godt akseptert av brukerne, og det tok bare et par minutter å fylle ut. Spørsmålene ble ikke oppfattet som provoserende.

HADS omfatter sju spørsmål om angst og sju om depresjon, som kommer annen hver gang. Hvert spørsmål har en ordinal svarskala med verdier fra null til tre, og nivået av angst og depresjon uttrykkes ved å beregne summen på delskalaene HADS-A og HADS-D. I noen sammenhenger er det naturlig å operere med totalskåren HADS-T, som er summen av delskalaene.

HADS hadde vært brukt i mange studier både innen somatikk og psykiatri (12). Psykometrien hadde vist seg god med høy intern konsistens, to stabile faktorer med korrelasjon på omkring 0,50 og god overensstemmelse med andre etablerte selvutfyllingsmål for angst og depresjon (12). Angstdimensjonen syntes i hovedsak å tappe angstfylt bekymring og anspenthet, mens depresjonsdimensjonen fokuserte på manglende livsglede (anhedoni) som av mange oppfattes som det sentrale fenomenet ved depresjon (13). I tråd med vanlig testtradisjon valgte vi i alle våre studier å substituere verdier for de respondentene som bare hadde fylt ut fem eller seks av de sju spørsmålene på delskalaene i HADS.

I flere studier var HADS blitt testet for kasusidentifikasjon opp mot ulike psykiatriske diagnoseinstrumenter. Det viste seg at en HADS-A eller HADS-D skår $\geq 8$ tilsa at personen muligens hadde en angstlidelse eller depresjon, mens skår på $\geq 11$ identifiserte slike lidelser med stor sikkerhet. Evnen til HADS som "case-finder" ble ikke testet i HUNT-II.

\section{Analyser basert på HADS i HUNT-II}

I tråd med at HUNT-II var et spleiselag bidro IDANTgruppen med en betydelig finansiering gjennom økonomiske bidrag fra Norges forskningsråd og Novo Nordisk Pharma AS. Gruppen leverte en omfattende prosjektbeskrivelse med mange delprosjekter til styringsgruppen for HUNT-II, og denne ble godkjent med mindre justeringer. Senere har denne planen blitt revidert, og utvidet med nye prosjekter. I tilfeller hvor andre forskergrupper ønsket å benytte HADS i HUNTII ble direkte avtaler inngått med IDANT-gruppen hvor nærmere bruk av variabler, gjennomsyn og medforfatterskap ble avtalefestet.

\section{Resultater}

\section{Etablering av forskningsmiljo for psykiatrisk epidemiologi}

IDANT-gruppen har medlemmer fra både Namsos og Levanger, og gruppen har sett det som hovedoppgave at det etableres forskningsmiljøer for psykiatrisk epidemiologi begge steder. En forutsetning for dette er at det finnes personer med forskningskompetanse på doktorgradsnivå, og dette var hittil ikke tilfelle. Utgangspunktet var at en hadde interesserte klinikere som ønsket å forske på HADS-data fra HUNT-II. Den første oppgaven var å skaffe disse klinikerne forskningstid, og dette ble ordnet i positivt samarbeid med klinikkledelsen begge steder. Neste oppgave var å finne aktuelle problemstillinger med angst og depresjon som avhengige variabler, og utforme disse som prosjekter med sikte på doktorgrader. Prosjektene ble lagt fram for og godkjent av styringsgruppen i HUNT-II. Sykehusene skaffet også nødvendig datautstyr og programvare som trengtes for analyse og publikasjon. Veiledning på forskning generelt ble gitt av professor dr. med. Alv A. Dahl og på statistikk og forskningsmetode av cand. polit. Arnstein Mykletun. De som gikk inn i denne satsningen var Eystein Stordal og Oddbjørn Johansen i Namsos, og Marit Bjartveit Krüger, Ottar Bjerkeset, Sigrid Bjørnelv, Nils Håvard Dahl og Anne Engum i Levanger. Bjerkeset er rekrutteringsstipendiat finansiert av Norges forskningsråd, og Bjørnelv har fått ett års klinisk stipend fra NFR til prosjektet sitt som bruker data fra UNGHUNT-materialet.

Det er nær forbindelse mellom HUNT forskningssenter Verdal og Sykehuset Levanger, og Bjerkeset og 
forskningsstipendiat Steinar Krokstad arbeider både der og ved Klinikk for psykiatri.

Forskerne i Nord-Trøndelag har lagt fram sine funn ved internasjonale symposier i Section for Epidemiology i både World Psychiatric Association og European Association of Psychiatrists. Videre har gruppen lagt fram på årsmøtene i Den amerikanske psykiaterforening og i Nordisk forening for psykiatrisk epidemiologi (NAPE). I den siste foreningen sitter Eystein Stordal i styret.

En gjenstående oppgave for IDANT-gruppen er bedre integrering av miljøene i Namsos og Levanger, noe som kan lettes ved den felles organiseringen $\mathrm{i}$ ett helseforetak etter sykehusreformen.

\section{Egenskapene til HADS}

Angst og depresjon kartlagt med HADS ble besvart med minst fem av sju spørsmål på hver delskala av 62.344 av de $65.220(95,6 \%)$ som fylte ut skjema 1 . De som hadde gitt fem eller seks svar på delskalaene ble substituert med gjennomnittet slik at delskalaene var komplette. De med færre svar på delskalaene ble ikke tatt mede i analysene av angst og depresjon. Svarprosenten på HADS varierte fra om lag 45\% i 20-29årsgruppen til litt over 80\% i aldersgruppen 60-69 år. Svarprosenten var generelt noen prosent høyere hos kvinner.

Det har vært naturlig å vurdere de psykometriske egenskapene til HADS slik testen har vært brukt $\mathrm{i}$ HUNT-II, og sammenligne funnene med de som ellers er gjort internasjonalt. Tidligere befolkningsdata på HADS bygger på mindre materialer fra Sverige (14) og Holland (15), og det har blitt publisert motstridende resultater hva angår de psykometriske egenskapene til HADS. Mykletun, Stordal og Dahl (16) studerte egenskapene til HADS i HUNT-II. De psykometriske egenskapene ved HADS i HUNT ble vurdert som gode. Ved faktoranalyse ble to separate faktorer som korresponderte med den teoretiske tofaktorstrukturen identifisert, og man fant videre at denne tofaktorstrukturen kunne identifiseres $i$ en rekke underutvalg definert ved somatiske og demografiske variabler. Videre ble det funnet god intern konsistens på hver delskala i alle 10års aldersgrupper i begge kjønn.

Egenskapene til HADS i HUNT-II ble også analysert av Børve og medarbeidere (17), hvor konfirmatorisk faktoranalyse med LISREL-modeller ble benyttet. De fant også at en tofaktormodell passet best med de foreliggende HADS data.

Ut fra størrelsen på HUNT-II materialet er det også nærliggende å publisere normdata for HADS-A og HADS-D i forhold til alder, kjønn, sivilstand og somatisk sykelighet. En slik publikasjon er under forberedelse av A.A. Dahl og medarbeidere.

\section{Intervensjonsstudien}

Som nevnt fikk IDANT-gruppen svært kort tid på å planlegge en intervensjonsstudie i forhold til HUNT- deltakere som viste høyt nivå av angst/depresjon. Gruppen visste ikke hvor mange individer legene $\mathrm{i}$ kommunene ville kunne undersøke og behandle, og den visste heller ikke noe om deres kompetanse i og interesse for psykiske lidelser. Gruppen valgte derfor å gjøre to forberedende tiltak. Det ene var å utvikle et diagnostisk hjelpemiddel: Strukturert Psykiatrisk Intervju for Allmennpraksis (SPIFA, 18), og det andre var å undervise leger og psykiatriske sykepleiere $\mathrm{i}$ forkant av at HUNT-II kom til deres kommune. SPIFA og opplæringen som særlig fokuserte på angstlidelser, depresjon og suicidalitet, ble godt mottatt og fremmøtet var bra. SPIFA ble videreutviklet på bakgrunn av de praktiske erfaringene, og rettighetene ble lisensiert til et farmasøytisk firma, som også lanserte det med stor suksess i Sverige og Finland. Hittil har mer enn 2000 norske allmennpraktikere vært på SPIFAkurs, og SPIFA brukes i opplæring av medisinerstudenter og ulike medarbeidergrupper innen psykisk helsevern. Diagnoseinstrumentet fra Nord-Trøndelag er dermed blitt allemannseie.

Etter at de første tusen deltakerne i HUNT-II var undersøkt, fant vi at en HADS-Total på $\geq 25$ identifiserte den ene prosenten av deltakerne med høyest nivå av angst/depresjon. Med en slik grense ville vi identifisere mellom 600 og 800 individer, og vi tenkte at dette antallet høyrisikoindivider ville allmennpraktikerne kunne ta hånd om. Når skjema 1 og svaret på blodprøver og fysiske målinger kom inn til SHUS, ble data lagt inn, og melding ble sendt til individer med HADS-T $\geq 25$ med beskjed om at de skulle ta kontakt med legen sin. Kopi av slike meldinger ble sendt til pasientenes allmennlege. For høye HADS-verdier var formuleringen: "Svarene dine tyder på at du har mye angst og depresjon, ta kontakt med legen din." Det var to ulemper med dette meldesystemet, nemlig at det tok seks uker fra deltakerne svarte til meldingen kom, og at meldingene kom sammen med meldinger om somatiske helseplager. Angst/depresjonsmeldingen kunne dermed lett komme bort $\mathrm{i}$ alle de andre meldingene.

I alt var det 654 individer som fikk melding om høyt nivå av angst/depresjon. Hvis de ikke meldte seg hos allmennpraktikeren innen fire uker, var det meningen at han/hun skulle kalle inn vedkommende. Legene skulle så ut fra sitt kjennskap til pasienten, og det han hadde lært på SPIFA-kurs, diagnostisere og behandle eller vurdere pågående behandling. Et meldeskjema om møtet mellom risikoindivid og lege skulle sendes til Levanger for anonym registrering.

Til sammen mottok vi 177 (27\%) slike meldeskjemaer fra primærlegene, resten ble innhentet av leger fra Psykiatrisk klinikk ved Sykehuset Levanger og Sykehuset Namsos som var involvert i HUNT. Sytten prosent av primærlegene i fylket ønsket av ulike grunner ikke å delta i IDANT. Hovedårsaken var at den psykiatriske intervensjonen ble opplevd som for arbeidskrevende, i tillegg ble alle de andre meldingene om ulike risikofaktorer og sykdommer sendt ut samtidig fra SHUS. Vi observerte best respons blant 
legene i de mindre kommunene og blant de som hadde fastlønnsavtaler.

Risikogruppen var i snitt ca. to år eldre og med en noe større kvinneandel enn resten av populasjonen. Av de under 67 år var $40 \%$ trygdet, mot $11 \%$ i resten av populasjonen. Bare 3,5\% av de som fikk melding, reagerte negativt på henvendelsen fra SHUS, resten var nøytrale eller positive. En av fire i intervensjonsgruppen var ikke kjent som psykisk lidende før primærlegen fikk meldingen fra SHUS. Omlag en tredel av risikogruppen gikk i regelmessig behandling hos primærlege eller spesialist når de møtte til HUNT-II. Omlag halvparten av de spurte ønsket aktiv deltakelse i IDANT. Som følge av IDANT ble det startet ny behandling mot angst og depresjon hos primærlege for $15 \%$ av gruppen og $7 \%$ ble henvist til psykiatrisk poliklinikk.

I etterundersøkelsen fire år senere ble et tilfeldig utvalg $(\mathrm{n}=300)$ av intervensjonsgruppen invitert, 55\% takket ja og ble intervjuet enten hjemme, på lokale legekontor eller psykiatrisk poliklinikk av NFRstipendiat Ottar Bjerkeset, psykolog Sara Larsson eller psykiatrisk sykepleier Erling Østnes ved Innherred sykehus. Av de 155 intervjuede hadde $47 \%$ en aktuell depressiv episode eller dystymi og omtrent like mange hadde en eller flere angstlidelser. Det var som forventet stor grad av komorbiditet. Denne gruppen representerte de antatt sykeste ( $>99$ percentil på HADS) når det gjaldt angst/depresjon i 1995-97.

Effekten av intervensjonen er vanskelig å bedømme siden randomisering til intervensjon av etiske grunner ikke ble tillatt i IDANT. Alle de 654 individene fikk med andre ord den samme meldingen fra SHUS og ble oppfordret til å søke lege. Samlet sett må vi si at intervensjonsstudien ikke var helt vellykket $\mathrm{i}$ den forstand at legene ikke gjorde det arbeidet vi ventet av dem. Dels kan det skyldes at meldingene om angst/ depresjon druknet i strømmen av somatiske meldinger, og dels at ikke alle legene var like innstilt på å gjøre noen psykiatrisk intervensjon. Samtidig har vi fått mange tilbakemeldinger på at studien økte bevisstheten om psykiske lidelser blant helsepersonell i kommunene.

\section{Depresjon og angst}

Med angst- og depresjonsmålinger på om lag 62.000 individer var det naturlig å studere prevalensen av slike symptomer i ulike kjønns- og aldersgrupper i befolkningen.

I befolkningsstudier hvor symptomer på depresjon er kartlagt ved både intervju og selvutfylling er stort sett funnet at angst og depresjon er mest fremtredende i middels voksen alder for så å avta i høyere alder. I sine analyser av depresjon målt med HADS-D fant Stordal et al. (19) et annet mønster, nemlig en lineær økning av depresjonsnivået fra 20 til 89 år både for menn og kvinner. I følge dette blir befolkningen bare mer og mer deprimert med økende alder. I et på- følgende arbeid har Stordal et al. (20) studert mulige årsaker til denne økningen i prevalensen av depresjon med økende alder. Resultatene indikerer at noe av årsaken i økningen kan tilskrives somatiske helseforhold og ulike funksjonstap, men i overkant av halvparten av økningen i depresjon med økende alder kan ikke forklares ved de anvendte teoretiske og statistiske modeller. En revidert versjon av dette er under innsendelse.

Tilsvarende analyser for angst er under utarbeidelse fra Bjartveit-Krüger og medarbeidere, og forekomsten av angst $\mathrm{i}$ forhold til kjønn og alder er helt annerledes enn for depresjon. Funnene for angst ser ut til å være mer i overensstemmelse med internasjonale funn.

En egen gruppe ('komorbiditetskameratene' bestående av Alv A. Dahl, Eystein Stordal, Ingvar Bjelland og Arnstein Mykletun) arbeider med problemstillinger omkring komorbiditet mellom angst og depresjon. Preliminære resultater antyder at de såkalte rene psykiatriske lidelsene, altså angstlidelser uten depresjon og vise versa, er sjeldne sammenlignet med de komorbide lidelsene, og særlig sjelden er symptomer på depresjon uten ledsagende angst.

En tilsvarende gruppe med tilnavnet 'årstidskameratene' bestående av Eystein Stordal, Gunnar Morken, Dag Neckelmann og Arnstein Mykletun studerer årstidsvariasjoner i angst og depresjon basert på at HUNT-populasjonen ble undersøkt i alle måneder unntatt juli.

Det ferdigstilles nå publikasjoner som beskriver årstidsvariasjoner i symptomer på angst, depresjon og søvnmønster, samt vegetative symptomer ved symptomer på depresjon.

\section{Angst, depresjon og coronar hjertesykdom}

Overlege Nils Håvard Dahl ser på sammenhengen mellom angst, depresjon og koronar hjertelidelse (KHS). Ved å etablere en 'bro' mellom fire like spørsmål om angst og depresjon i HUNT I og HUNT II, har en kunnet se på longitudinelle sammenhenger. Her viser det seg at angst er en risikofaktor for KHS som er sterkere enn røyking som risikofaktor. Videre ser en på sammenhengen mellom depresjon og totalkolesterol. Her kan en ikke finne noen sammenheng verken i totalmaterialet eller i undergrupper på kjønn og alder. En vil videre se på sammenhengen mellom parasuicid og kolesterol og parasuicid og angst og depresjon.

\section{Angst, depresjon og hormoner}

Overlege Anne Engum ser på sammenhengen mellom endokrine forstyrrelser, angst og depresjon. Sammenhengen mellom thyroidea-forstyrrelser og psykiske lidelser har vært i fokus siste 200 år, spesielt assosiasjonen mellom hypothyreose og depresjon. I undersøkelsen fant vi ingen sammenheng mellom verken funksjonsforstyrrelse av thyroidea-hormoner eller tilstedeværelse av thyroidea-antistoffer og angst eller depresjon. Derimot var en diagnostisert og tidligere kjent 
thyroidea-sykdom, uavhengig av funksjonsforstyrrelse, assosiert med både angst og depresjon (21).

Ved diabetes mellitus er det økt nivå av angst og depresjon, men bare ved diabetes mellitus type 2 . Denne assosiasjonen er på samme nivå som ved hjertekarlidelser, men lavere enn ved muskelskjelettlidelser, som det ble sammenlignet med. Det ser ut som om den subjektive opplevelsen av hemming og funksjonstap på grunn av somatiske plager er avgjørende for forekomsten av angst og depresjon blant personer med diabetes. Det gjenstår også å undersøke om det finnes undergrupper av diabetikere som har særskilt økt risiko for angst eller depresjon og om det er diabetes som er en risikofaktor, eller om det er andre faktorer assosiert med sykdommen (kjønn, alder, sosioøkonomisk status, fedme, røyking, inaktivitet, komorbiditet osv.) som påvirker nivået av angst eller depresjon.

\section{Forlopsstudie av angst og depresjon i ulike risikogrupper}

NFR-stipendiat Ottar Bjerkeset utførte i 2000-2001 en klinisk oppfølging 4-5 år etter den psykiatriske intervensjonen (IDANT), spørreskjema ble også sendt til en kontrollgruppe $(n=654)$ og et tilfeldig befolkningsutvalg $(\mathrm{n}=1308)$. Totalt deltok knapt $60 \%$. Gruppene vil bli fulgt videre med årsaksspesifikk død som endepunkt, det forventes i tillegg kobling mot sentrale registre.

Omlag 47.000 personer deltok i både HUNT-I og HUNT-II, og i analyser av denne gruppen ser Bjerkeset nå på hvordan ulike faktorer predikerer forløpet av angst- og depresjonssymptomer over flere år. Effekten av hjerteinfarkt og hjerneslag, betydningen av helserelatert atferd (mosjon, røyk og alkohol) og demografiske karakteristika er de viktigste problemstillingene. Blant de overlevende etter hjerteinfarkt i HUNT-II ser man en periode på opptil to år med betydelig øket risiko for depresjon, men bare hos kvinner, og det er ingen signifikant effekt på angstnivået. Det er søkt om kobling mot Dødsårsaksregisteret.

\section{Alkoholbruk}

Sosionom Oddbjørn Johansen har gjort deskriptive analyser av alkoholforbruk i frekvens og mengde samt risikofylt bruk kartlagt med CAGE. Det viser seg at de som er avholdsfolk og høykonsumentene begge har høyere depresjonsnivå $\mathrm{i}$ forhold til de som ligger mellom disse yttergruppene i forbruk.

\section{Spiseproblemer hos ungdom}

Parallelt med HUNT-II ble det gjennomført en ungdomsundersøkelse, UNG-HUNT, der alle elever $\mathrm{i}$ ungdomsskole og videregående skole ble invitert til å delta. Undersøkelsen besto av en spørreskjemadel og en klinisk del. 9131 ungdommer deltok, og av disse ga $88,1 \%$ valide svar på spørsmål som dekket aspekter ved spiseproblemer. I tillegg ble høyde og vekt målt, og BMI regnet ut.

I motsetning til alvorlige spiseforstyrrelser, er spiseproblemer ikke klart definert. I denne studien varierte prevalensen av spiseproblemer mellom $0,3 \mathrm{og}$ $47 \%$ avhengig av valgt definisjon. Ulike definisjoner ga ulik kjønnsratio, og forekomsten økte med alder hos jenter (22). Høyde og vekt ble benyttet til å utarbeide kjønns- og aldersjusterte BMI-percentiler. Disse ble sammenlignet med gjeldende norsk standard, og viste at det har vært en markert vektøkning for både gutter og jenter i alle aldersgrupper. Det er en skjev fordeling, med størst vektøkning i de høyeste percentilene (50-percentilen: $2-4 \mathrm{~kg}$, 97,5 percentilen: 9-14 kg).

\section{KONKLUSJON}

HADS viste seg å fungere bra i HUNT-II, ettersom nesten alle av de som møtte fram fylte ut de 14 spørsmålene. Vi fant altså at spørsmål om psykisk helse slett ikke var mer provoserende enn å svare på spørsmål om røykevaner eller hodepine. Totalt 60.869 returnerte gyldige responser på både angst- og depresjonsdelen, og dermed har HUNT-II det største materialet om angst og depresjon i verden. Det betyr at vi kan forholde angst og depresjon til livsstil, somatisk sykelighet, blodprøver og andre helseforhold som er målt $i$ HUNT-II. Dette er vi i gang med å analysere ved de psykiatriske klinikkene i Namsos og Levanger. Vi har engasjert psykiatere der i forskning på deltid med sikte på at iallfall seks av dem skal ta doktorgraden ved NTNU på HUNT-II materiale. Det betyr at de får vitenskapelig førerkort slik at de kan veilede andre, og dermed forutsetninger for å skape et bærekraftig forskningsmiljø. Angst og depresjon i HUNT-II har faktisk gitt oss så mye data at vi har startet en forskningsgruppe i Bergen som også jobber med dem. Det henger også sammen med at Helseundersøkelsen i Hordaland (HUSK) gir mulighet for sammenligning med og utvidelse av funn fra HUNT. På den måten skyter forskningen knopper, og vi får samarbeidende miljøer.

Takket være psykiatridata i HUNT har vi fått i gang det vi tror er et levedyktig psykiatrisk forskningsmiljø i Nord-Trøndelag i samarbeid mellom sykehusene og NTNU. I starten har det vært nødvendig med hjelp utenfra, men om et par år tror vi miljøet er selvbærende. Når forskning og klinisk arbeid går hånd i hånd, skaper det et mer levende miljø som rekrutterer interesserte fagfolk, og som i sin tur gir god pasientbehandling. Dette er en bra utvikling for psykiatrien $i$ Nord-Trøndelag både i kommune- og spesialisthelsetjenesten. 


\section{REFERANSER}

1. Robins LN, Regier DA. Psychiatric disorders in America. New York: Free Press, 1991.

2. Kessler RC, McGonagle KA, Zhao S, et al. Lifetime and 12-month prevalence of DSM-III-R psychiatric disorders in the United States. Arch Gen Psychiatry 1994; 51: 8-19.

3. Kringlen E, Torgersen S, Cramer V. A Norwegian psychiatric epidemiological study. Am J Psychiatry 2001; 158: $1091-8$.

4. St. meld. nr .25 (1996-97). Åpenhet og helhet. Om psykiske lidelser og tjenestetilbudene.

5. St. prp. nr. 63 (1997-98) Om opptrappingplan for psykisk helse 1999-2006.

6. Holmen J, Midthjell K, Bjartveit K, Hjort PF, et al. The Nord-Trøndelag health survey 1984-86. Verdal: Statens institutt for folkehelse: senter for samfunnsmedisinsk forskning, Verdal, 1990.

7. Zigmond AS, Snaith RP. The Hospital Anxiety and Depression Scale. Acta Psychiatr Scand 1983; 63: 361-70.

8. Bosnes O, Ellertsen B. Wechsler Memory Scale-Revised (WMS-R) anvendt på barn i Norge. Tidsskr Nor Psykologforen 2000; 37: 717-23.

9. Johansen E. Posttraumatiske stress-symptomer og mestring hos overlevende etter flyulykke. Delrapport fra prosjektet: "Psykiske ettervirkninger etter flyulykken i Berg, Overhalla, oktober 1993." Namsos: Psykiatrisk klinikk, 1998.

10. Nielsen AM. Akutte dissosiative reaksjoner hos overlevende og hjelpemannskaper fra en flykatastrofe. Delrapport fra prosjektet: "Psykiske ettervirkninger etter flyulykken i Berg, Overhalla, oktober 1993.” Namsos: Psykiatrisk klinikk, 1998.

11. Sexton H. Studies relating to the Treatment of Symptomatic Non-Psychotic Patients. Doktoravhandling. University of Trondheim, Faculty of Medicine, Dept. of Psychiatry and Behavioral Medicine, 1992.

12. Herrmann C. International experiences with the Hospital anxiety and depression scale - a review of validation data and clinical results. J Psychosom Res 1997; 42: 17-41.

13. Watson D, Weber K, Assenheimer JS, et al. Testing a tripartite model: I. Evaluating the convergent and discriminant validity of anxiety and depression symptom scales. J Abnorm Psychol 1995; 104: 3-14.

14. Lisspers J, Nygren A, Söderman E. Hospital anxiety and depression scale (HAD): some psychometric data for a Swedish sample. Acta Psychiatr Scand 1997; 96: 281-6.

15. Spinhoven PH, Ormel J, Sloekers PPA, Kempen GIJM, Speckens AEM, van Hemert AM. A validation study of the Hospital anxiety and depression scale (HADS) in different groups of Dutch subjects. Psychol Med 1997; 27: 363-70.

16. Mykletun A, Stordal E, Dahl AA. The Hospital Anxiety and Depression Scale (HAD): factor structure, item analyses, and internal consistency in a large population. Br J Psychiatry 2001; 179: 540-4.

17. Børve TA, Gjestad R, Bjerkeset O, Bjartveit Krüger M, Dahl NH, Stordal E, Dahl AA. Hospital anxiety and depression scale: confirmatory factor analysis and psychometric properties in a Norwegian sample. Innsendt til Acta Psychiatr Scand 2002.

18. Dahl AA, Bjartveit Krüger M, Dahl NH, Stordal E. Strukturert psykiatrisk intervju for allmennpraksis (SPIFA). Oslo: GlaxoSmithKline, 2000.

19. Stordal E, Dahl NH, Bjartveit Krüger M, Krüger Ø, Mykletun A, Dahl AA. Depression in relation to gender and age in the general population - The Nord-Trøndelag Health Study (HUNT). Acta Psychiatr Scand 2001; 104: 210-6.

20. Stordal E, Mykletun A, Dahl AA. The association between age and depression in the general population: a multivariate examination. Innsendt til Acta Psychiatr Scand 2002.

21. Engum A, Mykletun A, Dahl AA, Bjøro T. An association between depression, anxiety, and thyroid function a clinical fact or an artefact? Acta Psychiatr Scand (i trykken 2002).

22. Bjørnelv S, Mykletun A, Dahl AA. The influence of definitions on the prevalence of eating problems in an adolescent population. J Eating Weight Dis (i trykken 2002). 